\begin{tabular}{rlrr} 
Volume: & 2 & E-ISSN: & $2655-1942$ \\
Number: & 2 & Terbitan: & Oktober 2019 \\
Page : & $163-167$ & & \\
\hline
\end{tabular}

\title{
Antara Ratna Sarumpaet dan Ahmad Zahid Hamidi: Konsep Penahanan Indonesia Salah?
}

\author{
Luhut M.P Pangaribuan \\ Ketua Umum DPN Peradi, LMPP Advocates \& Counsellors at Law \\ Menara Kuningan 15th Floor, Jl. H.R. Rasuna Said Blok X-7, Kav. 5 \\ Jakarta 12940, Indonesia \\ Email:1mpp-law@lmpp-law.com
}

\begin{abstract}
Abstrak
Kesalahan dalam proses penegakan hukum lebih kejam dari pelanggaran hukum itu sendiri. Perbedaan proses pemeriksaan kasus Ratna Sarumpaet di Indonesia dan Ahmad Zahid Hamidi di Malaysia khususnya tentang penahanan, menjadi soal bagaimana memahami konsep penahanan dan pelaksanaannya yang benar. Berdasarkan hasil penelitian diketahui bahwa kesalahan penerapan konsep penahanan bisa mengakibatkan kerugian keuangan Negara karena setiap tahanan harus tetap hidup layak dengan segala fasilitas yang disyaratkan juga tidak akan mendukung peradilan yang adil atau fair trial. Bahkan lebih jauh sesungguhnya yang dilakukan bukan penahanan lagi tapi sudah kembali ke asasusulnya yaitu perampasan kemerdekaan yang merupakan satu perbuatan melawan hukum yakni tindak pidana sebagaimana diatur dalam pasal $333 \mathrm{KUHP}$.
\end{abstract}

Kata Kunci: Konsep Penahanan, Perbandingan Ratna \& Zahid (Indonesia \& Malaysia), Keadilan.

\begin{abstract}
Abstact
Mistakes in the process of law enforcement are crueller than the violation of the law itself. The difference in the process of examining the Ratna Sarumpaet case in Indonesia and Ahmad Zahid Hamidi in Malaysia, especially regarding detention, is a matter of how to understand the concept of detention and its proper implementation. Based on the research results it is known that the misuse of the concept of detention could result in state financial losses because every detainee must continue to live properly with all the required facilities nor would he support fair trials. Even further, what was actually carried out was not detention anymore but had returned to its principles, namely the deprivation of liberty which was an act against the law, namely the crime as regulated in article 333 of the Criminal Code.
\end{abstract}

Keywords: Concept of Detention, Comparison of Ratna \& Zahid (Indonesia \& Malaysia), Justice. 
Volume: 2

Number: 2

Page : 163-167
E-ISSN:

Terbitan:
2655-1942

Oktober 2019

\section{A. Latar Belakang}

Ratna Sarumpaet (Indonesia) Ahmad Zahid Hamidi (Malaysia), keduanya sedang menghadapi masalah hukum pada saat yang sama termasuk masalah penahanan. Ratna Sarumpaet masih berusaha meminta penangguhan penahanan atau perubahan status penahanan dari tahanan Rutan ke Tahanan Kota. Tapi belum berhasil malah penahanan diperpanjang 40 hari lagi oleh jaksa peneliti setelah sebelumnya sudah ditahan 20 hari oleh penyidik sebelumnya.

Berbeda dengan apa yang dialami Ahmad Zahid Hamidi, Presiden UMNO di Malaysia, dengan dakwaan (bukan sangkaan lagi) sebanyak 32 dakwaan dengan rincian 10 dakwaan menggunakan jabatan untuk melanggar hukum dan 27 tindak pidana pencucian uang dimana nilai seluruh dakwaan 114 juta ringgit. Sekalipun ia tidak mengaku bersalah (tidak kooperatif) tetap tidak ditahan dengan membayar jaminan 1 juta ringgit dan menyerahkan paspor nya. ${ }^{1}$

Pertanyaannya mengapa kepada Ratna penyidik Indonesia melakukan penahanan (kasus dugaan hoax) sementara penyidik Malaysia terhadap Zahid (kasus dugaan korupsi) tidak melakukannya? Apakah karena semata-mata beda sistem hukum dua Negara yang berbeda dan apakah sesungguhnya fungsi penahanan itu?

\section{B. Hasil Penelitian dan Pembahasan}

Ratna ditahan dalam Rutan (penjara) pada hal ada dua kemungkinan bentuk penahanan lagi yang dapat dilakukan yaitu tahanan rumah atau tahanan kota. Andaikata tahanan kota yang dilakukan penyidik maka Negara sesungguhnya lebih hemat karena tidak perlu menyediakan tempat tidur, makan dan lain sebagainya yang layak sesuai standar yang sudah ditentukan. Tidak ada data yang tersedia berapa biaya makan saja para tahanan di Indonesia. Tapi sebagai ilustrasi anggaran untuk makan Napi Negara pernah sampai terhutang Rp 300 Miliar. $^{2}$

\footnotetext{
${ }^{1}$ Agni Vidya Perdana, "Mantan Wakil PM Malaysia Dijerat 45 Dakwaan Korupsi Senilai Rp 408 Miliar ”, Kompas.com, 19 Oktober 2018.

${ }^{2}$ Kompas.com, 15 Juni 2016.
} 
Volume: 2

Number: 2

Page : 163-167
E-ISSN:

Terbitan:
2655-1942

Oktober 2019

Selain biaya makan biaya lain juga harus disediakan. Pada hal Indonesia juga komit bahwa penahanan tidak boleh mendegradasi hidup layak sekalipun kemerdekaannya sudah dikekang untuk pemeriksaan serta menerimanya sebagai fundamental rights (vide Body principles of UN 1988). Pertanyaannya mengapa tindakan yang tidak membebani Negara dan risiko pelanggaran HAM itu tidak dilakukan oleh penyidik tapi kecenderungan nya selalu menahan? Belum lagi bicara dampak penahanan ini terhadap objektivitas perkara itu sendiri. Penahanan oleh penyidik (sebelum persidangan) menurut banyak penelitian selalu potensial akan prejudice terhadap pemeriksaan perkara di pengadilan. Konkrit nya, menurut studi ICJR (2012) bahwa "Implikasi yang menonjol dari penggunaan penahanan pra-persidangan yang berlebihan...melemahkan asas praduga tidak bersalah...serta berkontribusi juga terhadap sesaknya sarana penahanan".

Kembali pada pertanyaannya mengapa kepada Ratna penyidik Indonesia melakukan penahanan sementara penyidik Malaysia tidak melakukannya? Kedua penahanan itu betul dilakukan di dua Negara yang berbeda, dan pada tindak pidana yang berbeda pula serta sistem hukum yang berbeda. Dilihat dari tindak pidananya dari sisi hukum Indonesia keduanya samasama kejahatan, jadi derajat keseriusannya sama. Bahkan lebih jauh dari sudut pandang hukum Indonesia bisa lebih berat lagi kejahatan Zahid karena dakwaannya tindak pidana korupsi dan pencucian uang, yang penegak hukum di sini selalu tekankan sebagai korupsi dan pencucian uang adalah extra-ordinary crime. Kalau begitu kenapa justru terbalik, penahanan extraordinary tidak ditahan sementara kejahatan biasa ditahan. Apakah konsep penahanan di Indonesia ada yang salah ?

Konsep penahanan secara umum bersifat universal. Hal ini dituangkan dalam United Nations Convention on Civil and political Rights dimana Malaysia dan Indonesia sebagai bagian konvensi itu. Indonesia bahkan sudah ratifikasi konvensi itu dengan UU No 12 tahun 2005. Artinya konsep dasar penahanan oleh penyidik di Malaysia dan Indonesia sama saja. Pertamatama harus dimengerti penahanan itu bersifat assessor kepada pemeriksaan pokok perkara. Maksudnya penahanan akan dilakukan apabila pemeriksan pokok perkara sungguh-sungguh memerlukannya. Sebab asasnya peradilan harus cepat, murah dan sederhana. Jadi dalam rangka melaksanakan asas itu barangkali penahanan menjadi diperlukan. Tapi ditentukan , “...dalam 
Volume: 2

Number: 2

Page : 163-167
E-ISSN:

Terbitan:
2655-1942

Oktober 2019

waktu satu hari setelah perintah penahanan itu dijalankan, ia harus mulai diperiksa oleh penyidik" (Pasal 122 KUHAP). Jadi pada dasarnya seseorang ditahan adalah untuk keperluan mempercepat pemeriksaan. Kemudian penahanan itu jangan pernah menjadi hukuman pendahuluan (cicilan) karena nantinya masa penahanan akan dipotong dari masa hukuman apabila hakim menjatuhkan pidana penjara. Selanjutnya, penahanan sebelum persidangan jangan sampai menimbulkan prejudice terhadap objektivitas pemeriksaan hakim di pengadilan nantinya. Terakhir penahanan jangan sampai merupakan pelanggaran fundamental rights.

Dalam ketentuan normatif sebagaimana diatur dalam KUHAP, penahanan bukan keharusan tapi hanya berdasarkan keperluan saja terhadap perkara dengan syarat yang sudah ditentukan, terhadap perkara dengan ancaman hukuman 5 tahun dan terhadap tindak-tindak pidana tertentu. Penahanan akan dilakukan, “...dalam hal adanya keadaan yang menimbulkan kekhawatiran bahwa tersangka atau terdakwa akan melarikan diri, merusak atau menghilangkan barang bukti dan atau mengulangi tindak pidana" (vide Pasal 21 (1) KUHAP). Kemudian, "Jenis penahanan dapat berupa: a penahanan rumah tahanan negara, b. penahanan rumah, c. penahanan kota,"( Pasal 22 (1) KUHAP). Selanjutnya, "Penyidik...berwenang untuk mengalihkan jenis penahanan yang satu kepada jenis penahanan yang lain..." (Pasal 23 ayat (1) KUHAP). Selanjutnya, dalam semua tahapan penahanan selalu ada klausul, “... tidak menutup kemungkinan dikeluarkannya tersangka dari tahanan sebelum berakhir waktu penahanan tersebut, jika kepentingan pemeriksaan sudah terpenuhi”. Atas penahanan yang dilakukan, “...atas permintaan tersangka... penyidik dapat mengadakan penangguhan penahanan dengan atau tanpa jaminan uang atau jaminan orang..." (Pasal 31 KUHAP).

\section{Kesimpulan}

Oleh karena itu apabila selama 20 hari dan diperpanjang 40 hari penahanan Ratna misalnya bila tidak dilakukan lagi pemeriksaan oleh penyidik terhadap dirinya maka sesungguhnya penahanan itu sudah tidak diperlukan. Perihal "melarikan diri, merusak atau menghilangkan barang bukti dan atau mengulangi tindak pidana" bila barang bukti sudah disita maka kekhawatiran melarikan diri sudah bisa diatasi dengan jaminan uang dan menyerahkan paspor seperti Zahid 
Volume: 2

Number: 2

Page : 163-167
E-ISSN:

Terbitan:
2655-1942

Oktober 2019

itu. khawatir mengulangi tindak pidana rasanya sulit dibayangkan terjadi apalagi sudah dalam pengawasan kepolisian dengan pemeriksaan perkaranya.

Oleh karena itu bila semua kekhawatiran sudah bisa dijamin tidak aka ada tapi tetap juga ditahan maka dapat disimpulkan maka alasan satu-satunya penahanan itu ialah kalimat yang mendahului klausula itu saja yaitu "dalam hal adanya keadaan yang menimbulkan kekhawatiran”. Kalau ini yang terjadi artinya selain penyidik tidak mempertimbangkan kerugian keuangan Negara karena setiap tahanan harus tetap hidup layak dengan segala fasilitas yang disyaratkan juga tidak akan mendukung peradilan yang adil atau fair trial. Bahkan lebih jauh sesungguhnya yang dilakukan bukan penahanan lagi tapi sudah kembali ke asas-usulnya yaitu perampasan kemerdekaan yang merupakan satu perbuatan melawan hukum yakni tindak pidana sebagaimana diatur dalam pasal 333 KUHP.

Oleh karena itu perbandingan pemeriksaan kasus Ratna dan Zahid di Malaysia khususnya tentang penahanan bisa dijadikan referensi bagaimana memahami konsep penahanan dan pelaksanaannya dengan benar. Sebab bagaimanapun kesalahan dalam proses penegakan hukum lebih kejam dari pelanggaran hukum itu sendiri.

\section{a) Kajian/ Studi}

\section{DAFTAR PUSTAKA}

Studi ICJR (2012)

\section{b) Artikel Majalah atau Koran}

Agni Vidya Perdana, “Mantan Wakil PM Malaysia Dijerat 45 Dakwaan Korupsi Senilai Rp 408 Miliar ”, Kompas.com, 19 Oktober 2018.

\section{c) Peraturan Perundang-Undangan}

vide Body principles of UN 1988

UU No 12 tahun 2005

KUHAP

KUHP 